九州大学学術情報リポジトリ

Kyushu University Institutional Repository

\title{
A SYNOPSIS OF THE BEE GENUS PALAEORHIZA PERKINS (HYMENOPTERA, COLLETIDAE) OF NEW GUINEA PART II. SUBGENERA GRESSITTAPIS, NOONADANIA, SPHECOGASTER, ANCHIRHIZA, CERATORHIZA
}

Hirashima, Yoshihiro

https://doi. org/10.5109/2381

出版情報 : ESAKIA. 12, pp.63-87，1978-11-30. Entomological Laboratory， Faculty of Agriculture， Kyushu University

バージョン :

権利関係 : 


\title{
A SYNOPSIS OF THE BEE GENUS PALAEORHIZA PERKINS \\ (HYMENOPTERA，COLLETIDAE) OF NEW GUINEA \\ PART II. SUBGENERA GRESSITTAPIS, NOONADANIA, SPHE COGASTER， ANCHIRHIZA，CERATORHIZA*
}

\author{
YOSHIHIRO HIRASHIMA \\ En tomologica 1 Laboratory, Faculty of Agriculture \\ Kyushu University, Fukuoka 812, Japan \\ and \\ Hikosan Biological Laboratory, Faculty of Agriculture \\ Kyushu University, Hikosan, Fukuoka 824-07, Japan
}

\begin{abstract}
A bstract
Eight species of Palaeorhiza belonging to five subgenera are discussed. Subgenera Gressittapis, Noonadania, Sphecogaster and Ceratorhiza are described as new. Five new species, P. (Gressittapis) miranda, P. (Noonadania) sculpturalis, P. (Sphecogaster) paradisea, P. (Sphecogaster) pernigra and P. (Ceratorhiza) rubrifrons are described. Males of $\mathbf{P}$. mandibularis and $\mathbf{P}$. conica are discovered. The Australian species P. (Anchirhiza) mandibularis is recorded from New Guinea for the first time.
\end{abstract}

In this paper eight species of Palaeorhiza belonging to five subgenera are discussed. Except for Anchirhiza Michener, four subgenera, Gressittapis, Noonadania, Sphecogaster and Ceratorhiza are described as new. These are considered to be most remarkable in the genus, and are morphologically very distinct. Especially the findings of Gressittapis, Noonadania and Sphecogaster are interesting in view of their unique characters.

Five new species, P. miranda, sculpturalis, paradisea, pernigra and rubrifrons are described. The males of mandibularis Michener and P. conica Michener are described for the first time.

The Australian species Palaeorhiza mandibularis Michener, the type species of Anchirhiza, is recorded from New Guinea for the first time. This is the first record of the species of Palaeorhiza which occurs both in Australia and New Guinea.

For the present paper I have seen the specimens from the B. P. Bishop Museum, Honolulu and the University Zoological Museum, Kopenhagen, includ.

* Contribution from the Entomological Laboratory, Faculty of Agriculture, Kyushu University, Fukuoka (Ser. 3, No. 54) and that from the Hikosan Biological Laboratory, Faculty of Agriculture, Kyushu University, Hikosan (Ser. 2, No. 39). 
ing those I collected in New Guinea in 1969 for the Bishop Museum. I am grateful to Dr. J. L. Gressitt and Dr. B. Petersen for their support of my study.

K EY to the subgenera of Palaeorhiza described in this paper

1. Side of pronotum with a longitudinal keel; collar of pronotum low, broad, dorsal face flat, anterior margin transversely straight, anterior and lateral margins sharply keeled and slightly reflected above, latero-apical corner of collar of pronotum triangularly projected; basal face of 1 st tergum broadly covered with dense, very short, scale-like white hairs ; similar scale-like hairs present on posterior and lateral faces of propodeum and side and underside of thorax; 2nd and 3rd terga each with a complete band of short, dense, appressed, white hairs on base; body black, not at all metallic, with conspicuous yellow markings on head and thorax; medium-sized, more or less robust spe-

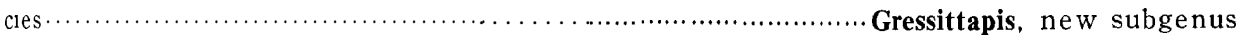

- Side of pronotum not carinate; collar of pronotum variable but neither carinate on apical and lateral margins nor projected triangularly on latero-apical corner; metasoma neither with covering of hairs on basal face of 1 st tergum nor with basal hair bands on 2 nd and 3 rd terga ; basic color variable $\ldots . . . . . . . . . . . . . .66$

2. Propodeum sharply divided into four parts, dorsal, dorso-lateral, posterior and lateral faces, by strong carinae; dorsal face of propodeum trapezoid in outline, horizontal, at least with a longitudinal, strong carina in middle; upper half of metepisternum distinctly depressed, this portion flat, and this depression extends forward toward upper portion of mesepisternum; strongly me-

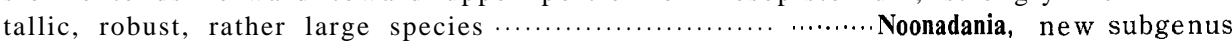

- Propodeum not carinate ; side of thorax normal; black species; metallic shade, when present, restricted to metasoma only

3. Scutellum. metanotum and propodeal enclosure horizontal in side view, especially in female; scutellum of female large, flat; metanotum also large, flat; propodeal enclosure large, flat, almost all dorsal; mandible of female extraordinarily broad and edentate at apex, that of male bidentate; clypeus small, very broadly separated from eye in female; male antenna with scape short (about three times as long as broad), flagellum elongate (with 2nd flagellar segment much longer than broad); hirsute and very densely punctate species, punctation on metasomal terga extraordinarily fine and dense...Anchirhiza Michener

- Propodeal enclosure unusually strongly convex ; 2nd flagellar segment of male

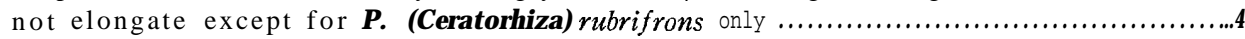

4. First metasomal tergum small, constricted and almost petiolate at base, a feature similar to Sphecoid wasps; 2 nd tergum highly convex in middle; hind spur of hind tibia of female dilated and curved near base; metasomal terga with broad impunctate apical margins; not hirsute species, head almost glabrous in front; head, thorax and metasoma black or metasoma alone slightly metallic; rather large to large, not so robust species........ Sphecogaster, new subgenus

- First metasomal tergum as usual; projection on propodeal enclosure conical; hind spur of hind tibia of female serrate or pectinate; rather hirsute, densely punctate species; metasomal terga without impunctate apical margins (when recognized they are linear); head and thorax black, with distinctive yellow markings, metasoma metallic, legs red; rather large to large, robust species

...Ceratorhiza, new subgenus 


\section{Gressittapis, new subgenus}

Type-species : Palaeorhiza (G ressittapis) miranda, new species

The new subgenus is represented by a single new species from W. New Guinea. This is very unique among subgenera of Palaeorhiza in many characters, some of which were listed in the key for the subgenera. Among them, the special mode of the coloration, punctation and hair decoration in addition to the unusual structure of the pronotum are really distinctive. It is very probable that Gressittapis may be regarded as a distinct genus when the male was discovered and the character of it was revealed.

\section{Description of the subgenus based on the female}

Medium-sized, more or less robust species.

Dull jet black, not at all metallic, with distinctive yellow markings on head and thorax (upper portion of clypeus, large lateral face mark, lower portion of supraclypeal area, pronotum, axilla, scutellum, metanotum, propodeal enclosure, lateral lobe of pronotum, upper mark on pre-episternum and upper mark on metepisternum yellow) ; unusually, yellow portions thick and mostly subtranslucent.

Not hirsute species ; 2nd and 3rd terga with basal hair bands of dense, short, appressed white hairs; basal area of 1 st tergum broadly covered with very short, dense, scale-like white hairs; similar scale-like white hairs on posterior and lateral faces of propodeum and side and underside of thorax; apex of metasoma with hairs yellowish brown.

Maxillary palpi rather long, 6-segmented ; labial palpi very short, 4-segmented; mandible bidentate ; lateral margin of clypeus above anterior tentorial pit straight; upper margin of clypeus transversely straight; facial fovea conspicuous, long, extending down to level of upper margin of antenna1 sockets ; ocelli rather small; vertex well convex in frontal view; preoccipital carina distinct.

Collar of pronotum low, broad (when seen from above), thick (when seen from side), sharply truncate anteriorly and lateral\&, anterior margin transversely straight when seen from above, anterior and lateral margins sharply edged and reflected above, latero-apical corner of collar of pronotum triangularly projected; this feature of collar of pronotum very unusual for Palaeorhiza; side of pronotum longitudinally carinate (this is also unusual for Palaeorhiza) ; propodeal enclosure large, slightly elevated, well indicated by absence of punctures and coloration (entirely subtranslucent yellow in contrast to dull jet black adjacent area), with about 13 longitudinal wrinkles; thorax very strongly, very densely, mostly macro-punctate except for pronotum, scutellum, metanotum, propodeal en closure, lateral face of propodeum and metepisternum.

Wings more or less short ; stigma slightly broadened; 2nd submarginal cell about three-fourths as long as 1st.

Fore tarsi with 1st segment very slightly longer than next four segments together except claw, 2nd to 4th segments small, slightly modified; basal area of hind tibia unmodified; inner spur of hind tibia normal.

Metasoma long elliptical; 1st tergum with basal area broadly flat, although 
slanting; base of 2nd tergum constricted ; metasomal terga minutely roughened, entirely dull, 1st and 2nd terga with ultra-micro- and extremely dense punctures.

Distribution : W. New Guinea.

Etymology: The new subgenus is named in honor of Dr. J. L. Gressitt, Wau Ecology Institute, Papua New Guinea, for his outstanding contribution to the entomology in the Pacific. The second component of the new name, -apis, is adopted from the Latin apis, the feminine.

\section{Palaeorhiza (Gressittapis) miranda, new species}

Unfortunately this new species is known by the holotype female only. This species may easily be recognized by its unusual features of the coloration, punctation and hair decoration in addition to the unique characters of the pronotum.

Female: Length about $9 \mathrm{~mm}$; fore wing about $7.5 \mathrm{~mm}$.

Relative head measurements : width, 40; length, 34; eye length, 29; upper interocular distance, 22; width of face, 25 ; lower interocular distance, 18; length of clypeus, 15 (approximately $12+3$ ). Inner eye margins distinctly converging below except for upper about one-fifth which converges toward ocelli; vertex convex, well beyond level of summits of eyes in frontal view; mandible narrowed toward bidentate apex ; malar space narrow anteriorly, slightly widened posteriorly; clypeus more or less narrow on upper margin, which is transversely straight, distinctly widened toward apex; clypeo-ocular distance rather short, slightly longer than anterior length of malar space; lower half of face well convex; supraclypeal area distinctly convex, with a strong, longitudinal, deep, median sulcus on upper portion; ocelli more or less small ; postocellar distance longer than diameter of lateral ocellus, about half as long as ocellocular distance which is about as long as ocelloccipital distance; genal area rather broad, well convex, a little broader than eye seen from side. Flagellum short, more or less thick apically; 1st segment about as long as wide, longer than 2nd which is almost ring-like, 3rd about as long as wide, about as long as 4 th.

Collar of pronotum as described for subgenus; side of pronotum longitudinally carinate; scutellum, metanotum and propodeal enclosure broadly flat; the latter, which is sharply defined from the rest of propodeum by absence of punctures and coloration, with about 13 longitudinal wrinkles; underside of thorax with a A-shaped keel in front of mid coxa very strong. Wings with stigma slightly broadened; 2nd submarginal cell about three-fourths as long as 1st. Legs slender; fore tarsus with polliniferous hairs well developed, 1st segment very slightly longer than next four segments together except claw, 2nd to 4th segments small, rather flattened, with inner apical lobe exceeding outer (this reminds of that of the female conica); basal portion of hind tibia rather broad, without special modification ; inner hind tibia1 spur as usual. Metasoma long elliptical ; 1st tergum with basal area broadly flat (although slanting) ; base of 2nd tergum, which is well convex in middle, distinctly constricted; 

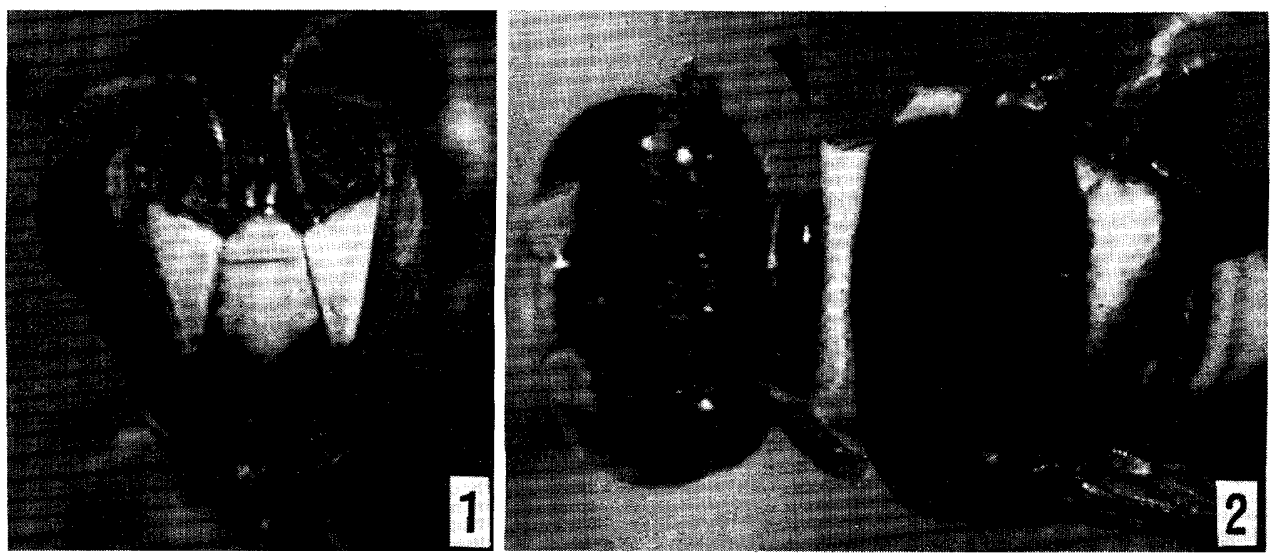

Figs. 1-2. Palaeorhiza (Gressittapis) miranda, new species. 1: Frontal view of the head of the holotype female. 2: Dorsal view of the anterior part of the body of the holotype female. The arrow points the collar of the pronotum which is characteristic to Gressittapis, new subgenus.

apex of 6th tergum narrowed but not sharply pointed.

Clypeus, supraclypeal area and lower half of paraocular area smooth, shining, with not strong punctures irregular in size and distribution; upper half of face above antennae, vertex and upper portion of genal area strongly and densely rugoso-punctate on dull, microscopically roughened ground. Mesoscuturn very strongly, very densely, coarsely rugoso-punctate on dull and microscopically roughened ground, punctures irregular in size, almost foveolate ; scutellum dull, with more or less roughened surface; metanotum dull, with fine surface; propodeal enclosure large triangular with outer margin slightly convex outwardly, surface fine, with about 13 longitudinal wrinkles; dorso-lateral and posterior faces of propodeum considerably strongly rugoso-punctate on entirely dull ground ; pre-episternum and mesepisternum with rather dense macropunctures ; metepisternum impunctate, transversely strongly carinate. Metasomal terga entirely dull, very minutely roughened all over (including basal face of 1st tergum), with no apical impunctate margin; 1st tergum with ultrasmall, exceedingly dense punctures ; 2nd with punctures more finer than those on 1st; 3rd and following terga without visible punctures.

Color: Head and thorax dull jet black except for lower half of face shining and lower half of genal area weakly shining; head and thorax with following marks or areas yellow (yellow portions unusually thick, translucent on head, subtranslucent on thorax) : upper half of clypeus, lower portion of supraclypeal area, large lateral face mark, collar of pronotum, axilla, scutellum, metanotum, propodeal enclosure, lateral lobe of pronotum, longitudinal mark on upper portion of pre-episternum and transverse mark on upper portion of metepisternum ; lower half of clypeus piceous or more reddened; a pair of small yellowish spots on upper portion of supraclypeal area; scape piceous, yellowish beneath behind; flagellum reddish brown beneath. Wings slightly brownish ; stigma and veins brownish ; tegulae reddened. Legs reddish brown; 
apices of fore and mid femora and bases of fore and mid tibiae yellowish. Metasoma dull black but partly dark reddish brown (apical margins of terga, for example), not at all metallic.

Hairs: Hairs scanty; mesoscutum with very sparse, suberect, more or less long, brownish hairs ; underside and side of thorax (except for most part of pre-episternum and mesepisternum), posterior face of propodeum and hind coxa with very short, mostly scale-like, dense, white hairs; basal area of 1 st tergum also broadly covered with very short, dense, scale-like, white hairs; basal margins of 2 nd and 3rd terga each with a complete band of dense, short, appressed, white hairs ; hairs on apex of metasoma yellowish, not darkened.

Type material and type depository: Holotype female (BISHOP 11424), Vogelkop: Bomberi, 700-900 m, W. New Guinea, June 10, 1959 (T. C. Maa), in the B. P. Bishop Museum, Honolulu.

Distribution: W. New Guinea.

\section{Noonadania, new subgenus}

\section{Type-species: Palaeorhiza (Noonadania) sculpturalis, new species}

The new subgenus is known by two species, one is from New Guinea and another from the Bismarck Archipelago. The new subgenus is very distinctive in the characters of the propodeum and metepisternum. The propodeum is provided with very strong carinae which divide the propodeum into four clearcut areas, i. e., the dorsal, dorso-lateral, posterior and lateral areas. The dorsal area is horizontal and trapezoid in outline. The metepisternum is strongly depressed on the upper portion and this depression extends forward to the upper portion of the mesepisternum. Thus, this subgenus is easily distinguished from others by such unusual characters. In addition, the species of this subgenus are robust in a general habitus, and the wing is rather short. It is probable that this subgenus may be regarded as a distinct genus when the male was discovered and the characters were revealed. Unfortunately the new subgenus is known by the female only.

\section{Description of the subgenus based on the female}

Rather large, robust species; wings rather short.

Strongly metallic, with yellow markings restricted to side of face and side of pronotum only. Wings subhyaline (in the type species) or distinctly darkened.

Hairs scanty; hairs on head and thorax brownish in the species from the Bismarck Archipelago, whitish in the type species; hairs on metasoma fuscous or black.

Mandible rather broad, obliquely tridentate (with the uppermost tooth weak) ; malar space long but shorter than basal width of mandible; clypeus well convex, broadly separated from eye (clypeo-ocular distance at least as long as diameter of antenna1 socket); space between ocelli and preoccipital carina with anterior half (near ocelli) subhorizontal, posterior half strongly slanting. 

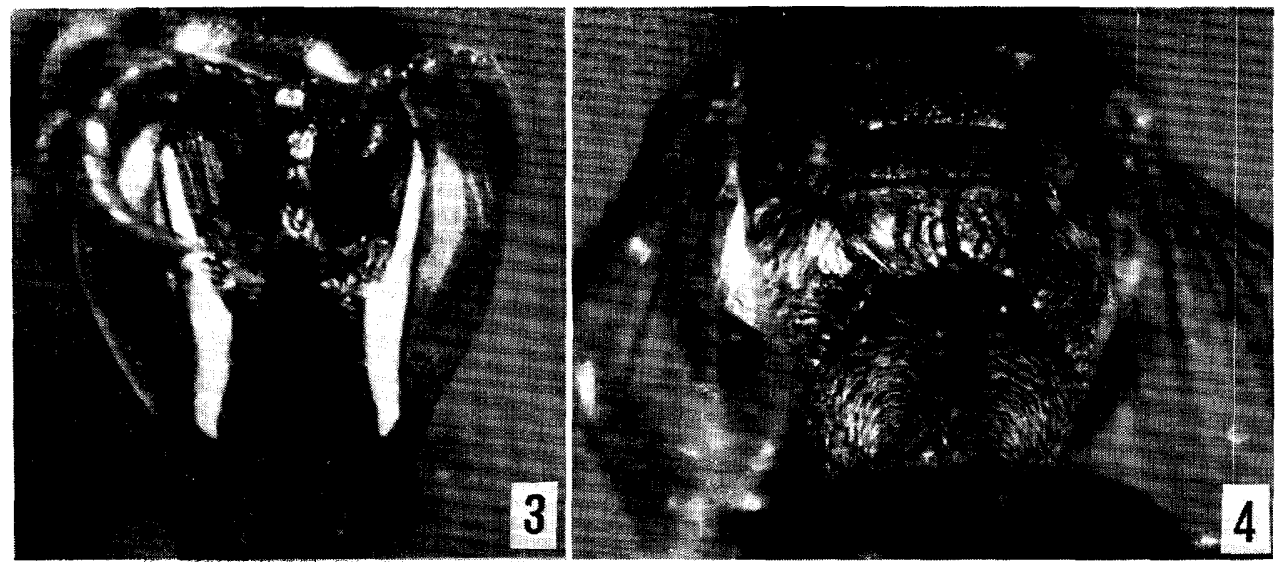

Figs. 3-4. Palaeorhiza (Noonadania) sculpturalis, new species. 3: Frontal view of the head of the holotype female. 4: Postero-dorsal view of the propodeum, which is unusually sculptured for the species of Palaeorhiza, of the holotype female.

Collar of pronotum low, slightly broadened on side only, for most part the upper face linear or ridge-like, transversely nearly straight in frontal view; propodeum clearly divided into four areas, dorsal, dorso-lateral, posterior and lateral, by strong carinae; dorsal area of propodeum horizontal, almost trapezoid in outline, at least with a longitudinal carina in middle; lateral face of propodeum transversely carinate behind near posterior face of propodeum; upper portion of metepisternum distinctly depressed, broadly flat; this depression extends forward to upper portion of mesepisternum.

Wings rather short; stigma slender; 2nd submarginal cell about two-thirds as long as 1st.

Legs rather robust, more or less short; fore tarsus with 1st segment approximately as long as next four segments together except claw, 2nd about as long as broad, indistinctly larger and longer than 3rd, 4th broader than long; posterior spur of hind tibia normal (minutely siliate) ; basal area of hind tibia of female well marked, smooth, impunctate, free of hairs.

Metasoma broad, well convex; in the type-species, 1st tergum very broad, rather short, well convex, with steep basal face; apex of 6th tergum narrow but not pointed, with covering of rather short, rather dense, fuscous or black hairs.

Distribution: New Guinea and Bismarck Archipelago (New Britain and New Ireland).

Etymology: The name of the new subgenus was derived from the Noona Dan Expedition (Dr. B. Petersen, Copenhagen), by which a number of interesting species of Palaeorhiza, including a species which belongs to Noonadania, were collected from the Bismarck Archipelago.

$$
\mathrm{K}_{\text {EY }} \text { to the FEMALES OF Noonadania }
$$

1. Head green with slight purple and bluish tints; lateral face mark long, rather broad, ivory; punctures on head distinct even on clypeus (although longitu- 
dinal on the latter) ; hairs on head white or grey, only slightly brownish on vertex only; thorax blue-green with purple tint; mesoscutum microscopically tessellate, nearly dull, with strong punctures irregular in distribution; dorsal area of propodeum with median portion excavated and longitudinally irregularly carinate; transverse carinae on lateral face of propodeum very strong; depression on upper portions of mesepisternum and metepisternum broad and distinct; wings subhyaline, slightly darkened apically; metasoma broad basally, shining, more bluish than in thorax with strong purple shade; punctures on metasoma distinct, although not dense-.sculpturalis, new species from New Guinea

- Head dark green with coppery shade; lateral face mark narrower and sometimes shorter, creamy yellow; hairs on head brownish ; thorax dark bluegreen with slight coppery and purple shades; mesoscutum smooth, shining, with weaker punctures; dorsal area of propodeum with fewer longitudinalcarinae except for the niedian carina which is as distinct as in sculpturalis; depression on upper pdrtions of mesepisternum and metepisternum weaker; wings distinctly brownish; metasoma derker in color than in sculpturalis, with weaker and sparser punctures ............ Unnamed species from Bismarck Archipelago

\section{Palaeorhiza (Noonadania) sculpturalis, new species}

This new species is known by the holotype female only from New Guinea. This species is separable from a consubgeneric, unnamed species from the Bismarch Archipelago by the characters listed in the key. The recognition of this species is rather easy because of its unique characters shown in the description for the subgenus.

Female: Robust, length about $10 \mathrm{~mm}$; fore wing less than $8 \mathrm{~mm}$.

Relative head measurements : width, 45; length, 41; eye length, 33; upper interocular distance, 22; width of face, 27; lower interocular distance, 21; length of clypeus, 18 (approximately $11+7$ ). Inner eye margins slightly converging below except for upper one-fifth which strongly converges toward ocelli; mandible broad, tridentate with two lower teeth distinct; malar space slightly shorter than basal width of mandible in middle ; clypeo-ocular distance longer than long axis of mid ocellus; clypeus and supraclypeal area well convex, the latter slightly dilated laterally on upper portion, more or less gently reducing its hight toward above; region of frontal line somewhat convex longitudinally; ocelli not large, well separated from each other ; postocellar distance much longer than diameter of lateral ocellus, slightly shorter than ocellocular distance. Flagellum rather short, with 1st segment broader than long, about as long as 2nd, 3rd very slightly longer than broad (or about as long as broad), slightly shorter than 1st and 2nd taken together. Collar of pronotum linear or ridge-like dorsally, slightly broadened on side only; mesoscutum, scutellum and metanotum well convex; dorsal area of propodeum, which is trapezoid in outline, horizontal, median portion excavated and longitudinally irregularly carinate, with a median, longitudinal carina very strong; posterior face of propodeum strongly carinate on margins; dorsolateral face of propodeum also strongly carinate on side ; lateral face of propodeum with about five, very strong, transverse carinae on lower (posterior) portion ; upper portion of metepisterum strongly depressed, this portion flat, and this depression extends 
forward to upper portion of mesepisternum; underside of thorax with a $L^{-}$ like strong carina in front of mid coxa. Wings rather short; stigma slender, long; 2nd submarginal cell about two-thirds as long as 1st. Legs more or less short, rather robust; basal area of hind tibia shining, well indicated by absence of both hairs and punctures. Metasoma broad at base (1st tergum), well convex; apex of 6 th tergum more or less rounded.

Clypeus longitudinally lineolate-punctate, shining ; frons distinctly punctate on microscopically and longitudinally lineolate, rather dull ground; vertex more shining, rather coarsely rugoso-punctate ; narrow, impunctate, shining space lateral to lateral ocellus. Mesoscutum strongly punctate on microscopically tessellate, rather dull ground, punctures not dense, irregular in size and distribution; scutellum slightly more smooth and shining than in mesoscutum, sparsely punctate; punctures on metanotum very small ; latero-basal portion of dorsal area of propodeum impunctate, finely lineolate, shining; dorso-lateral face of propodeum with very small, not dense punctures, not coarsely sculptured; posterior face of propodeum rather coarsely sculptured; lateral face of propodeum minutely shagreened, dull ; pre-episternum shining, densely punctate; depressed upper portions of mesepisternum and metepisternum nearly smooth, highly shining, with sparse, ultra-microscopical punctures and indication of transverse, microscopical lineolation. Metasoma with 1st tergum nearly smooth, highly shining, sparsely and very weakly punctate, apical impunctate margin broad, not sharply defined; 2nd tergum with stronger, still sparse punctures on microscopically lineolate, shining ground, apical impunctate margin broad, well indicated; 3rd tergum more punctate and more lineolate than in 2nd, apical impunctate margin narrower, also well indicated,

Color: Head shining green with bluish and purple shades ; longitudinal, broad mark on side of face ivory; flagellum brown beneath. Thorax bluegreen with purple shade; small mark on side of collar of pronotum ivory. Tegulae brown with purple and blue-green shades; wings subhyaline, distal portions slightly darkened; stigma and veins brownish. Legs piceous with strong blue-green and slight purple shades; small segments of tarsi mostly brownish. Metasoma shining blue-green or more bluish with strong purple shade especially on 1st tergum and on venter.

Hairs : Hairs scanty; hairs on head whitish except for those on vertex slightly brownish ; mesoscutum with very short, sparse, slightly brownish hairs; hairs on side of thorax and propodeum whitish; hairs on metasoma brown including those on 6th tergum not long; 1st and 2nd terga bare dorsally,

Type material and type depository: Holotype female (BISHOP 11425), Waris, S. of Hollandia, W. New Guinea, 450-500 m, August 1-7, 1959 (T. C. Maa), in the B. P. Bishop Museum, Honolulu.

Distribution : New Guinea.

\section{Palaeorhiza (Noonadania) sp.}

Two females from New Ireland and two females from New Britain taken by the Noona Dan Expedition were examined. This is a good species closely 
resembles sculpturalis as stated in the key. The description of this species will be appeared in a separate paper.

\section{Sphecogaster, new subgenus}

Type-species : Palaeorhiza (Sphecogaster) paradisea, new species

The new subgenus, which is known by two new species from New Guinea, is very distinctive in having the 1 st metasomal tergum being constricted and subpetiolate at the base, a feature similar to the Sphecoid wasps. This is certainly a remarkable structure for the bees. Sphecogaster is further characteristic in having the propodeal enclosure being strongly elevated in the middle, a feature similar to Ceyatoyhiza, another new subgenus of Palaeorhiza described in this paper. Thus, Sphecogaster is easily recognizable by the combination of these unusual characters.

\section{Description of the subgenus}

Rather large to large species, not very robust.

Head shining black, with yellow markings on face of male only (male of pernigra is unknown, however), thorax black; metasoma black, with slight metallic shade in the type species only; legs yellow or black; wings variable in color.

Hairs scanty on head, especially in front; thorax slightly hairy, but hairs on mesoscutum short and sparse; metasoma scanty of hairs dorsally; apex of 6th tergum of female without covering of short dense hairs; fringe-like white hairs on latero-apical portion of 1st tergum distinct in pernigra, obscure in female paradisea, absent in male paradisea.

Mandible weakly tridentate in female, distinctly bidenate in male; malar space at least one half as long as basal width of mandible; clypeus broadly flattened, distinctly separated from eye ; supraclypeal area with upper portion highly elevated, dilated laterally, sharply defined from frons above; ocelli large ; posterior ocelli on top of vertex. Flagellum more or less long, 1st segment longer than broad, 2nd broader than long, 3rd about as long as broad (or indistinctly broader than long), shorter than 4th which is as long as 5th. Head without distinct punctures in front, shining; vertex weakly punctate.

Mesoscutum well convex ; axilla conically slightly convex ; propodeum rounded as usual ; propodeal enclosure very strongly elevated in middle; carina on lower portion of thorax in front of mid coxa very strong. Thorax well punctate.

Wings long; stigma large ; 2nd submarginal cell large, at least threefourths as long as 1st.

Legs slender as usual; inner hind tibial spur of female dilated and curved subbasally; basal portion of hind tibia of female slender, with a slender, longitudinal, weak elevation ; fore tarsus with 1st segment not specially elongate (shorter than next four segments together), 2nd longer than broad, indistinctly larger than 3rd, 4th about as long as broad.

Metasoma with 1st tergum small, constricted and subpetiolate at base; 2nd tergum highly convex in middle, strongly depressed at base; impunctate apical 


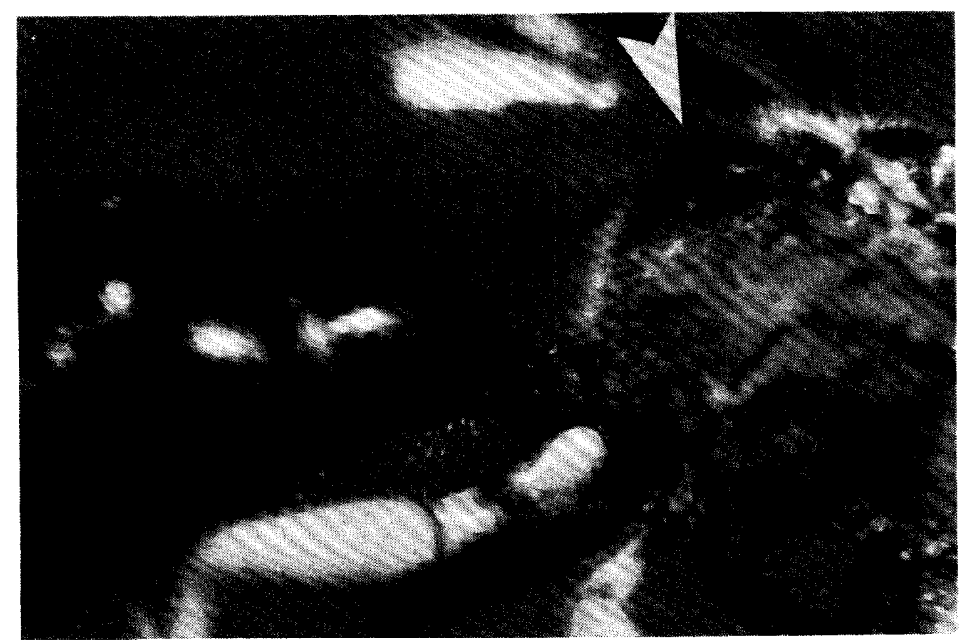

Fig. 5. Palaeorhiza (Sphecogaster) paradisea, new species. Lateral view of the posterior part of the thorax and the basal part of the metasoma of the female. The white arrow points the elevation of the propodeal enclosure and the black arrow indicates the subpetiolate 1st tergum, both are characteristic to Sphecogaster.

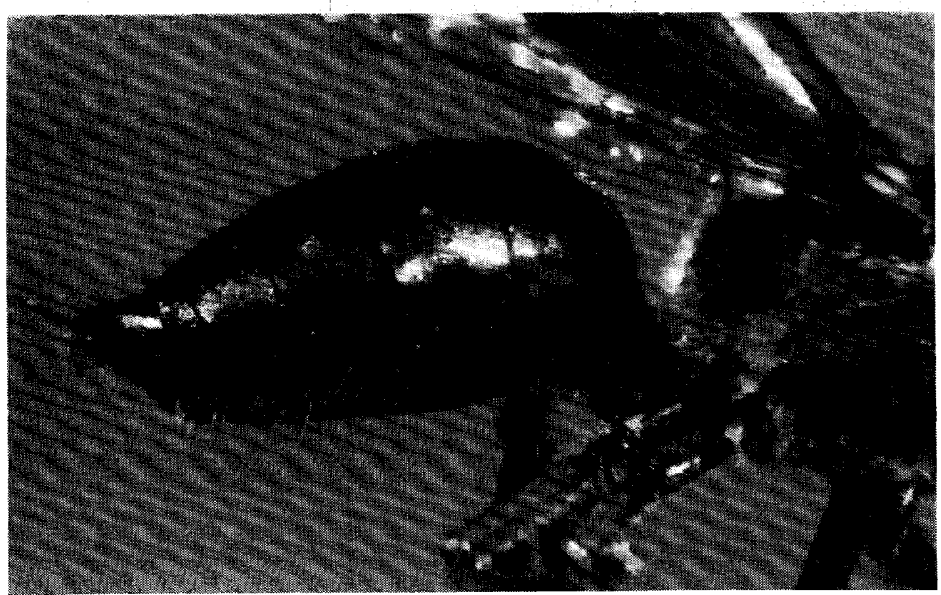

Fig. 6. Palaeorhiza (Ceratorhiza) conica Michener. Lateral view of the metasoma and the posterior part of the thorax. Note the 1st tergum which is short, broad and well convex as usual for the species of Palaeorhiza.

margins of basal four terga broad and well indicated; apex of female 6th tergum rather broad, slightly rounded; sterna of male without special modification; 5th sternum of male with apical fringe of curled hairs distinctive at each side. Genitalia of male small, not specially modified.

Distribution : New Guinea.

Etymology: The name of the new subgenus refers to the character of the 1st metasomal tergum which is small and constricted and subpetiolate at the base, a feature similar to the Sphecoid wasps. The second component of 
the new name, -gaster, is adopted from the Greek gaster, the feminine.

K EY to the SPEcies of Sphecogaster

1. Female: smaller, length about $11 \mathrm{~mm}$; head black, distinctly shining and almost free of hairs in front; thorax black, mesoscutum shining; tegulae brownish, partly subhyaline ; legs yellow; wings distinctly darkened; metasoma black, rather shining, with weak metallic (mixture of blue, green and purple) shade; head not elongate in frontal view; malar space shorter than basal width of mandible; propodeal enclosure very strongly convex, with a shaped keel-like projection; hairs on apex of metasoma fuscous. Male : malar space as long as basal width of mandible; clypeus rather narrow (therefore more broadly separated from eye than in female), long, broadly flat, without longitudinal elevation in middle; face with yellow markings on clypeus and lower paraocular area or further on labrum and mandible .......................

paradisea, new species

- Female: larger, length about $13 \mathrm{~mm}$; entirely black including legs; metasoma with slight iridescent reflection on apical impunctate margins which are broad; tegulae fuscous; wings subhyaline with distal margins slightly darkened ; head distinctly elongate in frontal view; malar space as long as basal width of mandible; mesoscutum strongly, somewhat rugosely punctate on microscopically roughened, rather dull ground; elevation of propodeal enclosure weaker. although distinctive; hairs on side and apex of metasoma white ; rather dense, white hairs on latero-apical portion of 1 st tergum conspicuous and fringe-

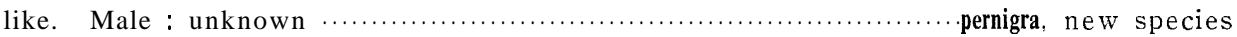

\section{Palaeorhiza (Sphecogaster) paradisea, new species}

This new species is easily known by the combination of unusual characters stated in the description of the subgenus, in addition to the specific coloration of the integument (black body with yellow legs).

Female: Length about $11 \mathrm{~mm}$, fore wing about $10 \mathrm{~mm}$.

Relative head measurements : width, 44; length, 40.5 ; eye length, 33.5; upper interocular distance, 21; width of face, 27; lower interocular distance, 21; length of clypeus, 18 (approximately $12+6$ ). Inner eye margins more or less distinctly converging below except upper about one-fourth which more converges toward ocelli ; mandible tridentate with innermost tooth weak; malar space rather long, oblique, more than half as long as basal width of mandible in middle; clypeo-ocular distance about as broad as anterior width of malar space ; clypeus broadly flat, with a weak, median, longitudinal elevation; upper portion of supraclypeal area distinctly dilated laterally, highly elevated, and sharply defined from frons; ocelli rather large; postocellar distance slightly less than diameter of lateral ocellus, a little more than half of ocellocular distance, less than half of ocelloccipital distance; space between ocelli and preoccipital carina slightly concave transversely in middle. Mesoscutum well convex; axilla slightly conically convex ; scutellum with median portion slightly depressed; propodeal enclosure very strongly convex in middle, with a $\backslash /$-shaped, keel-like projection, dividing the enclosure into two parts, a basal, subhorizontal (slanting toward base), semicircular space and an apical, strong- 
ly slanting part. Stigma large; 2nd submarginal cell about three-fourths as long as 1st. Posterior spur of hind tibia dilated and curved near base. First tergum small, constricted and subpetiolate at base; 2nd tergum highly convex in middle, distinctly depressed at base; apex of 6 th tergum broad, slightly rounded.
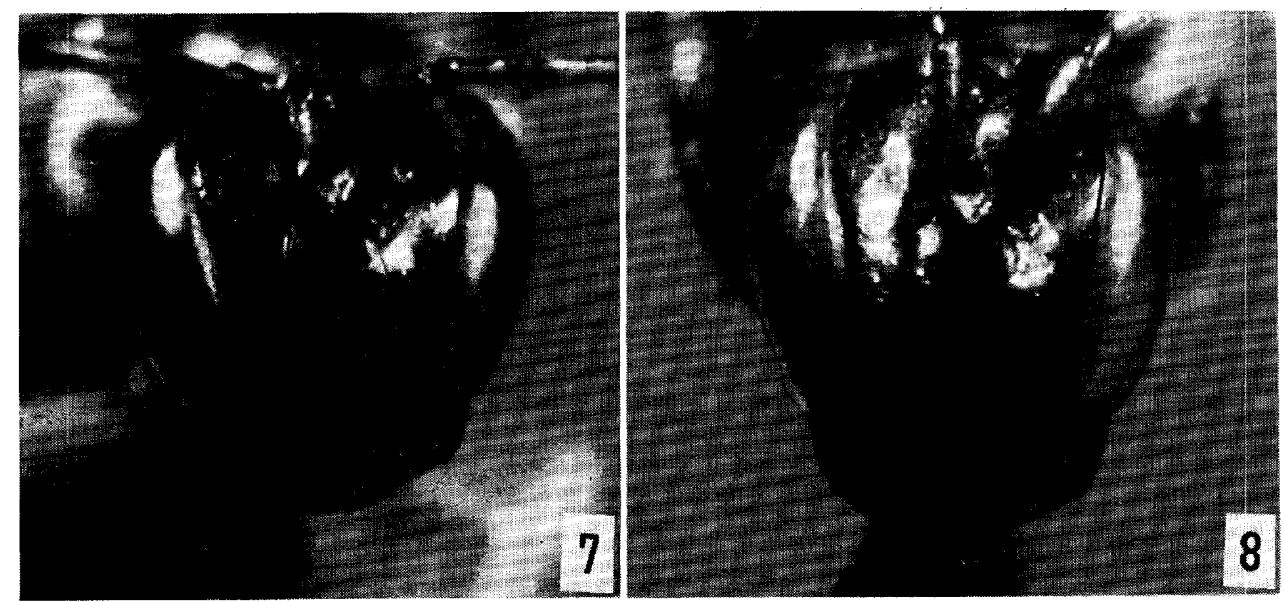

Figs. 7-8. Frontal view of the female head of Sphecogaster. 8: P. (S.) paradisea, new species. 9: P. (S.) pernigra, new species.

Head shining in front; clypeus, supraclypeal area, psraocular area and frons very finely longitudinally lineolate, with sparse, very weak punctures; frons broadly impunctate, especially on upper portion of antenna1 socket; upper portion of frons lateral to median ocellus with weak punctures; vertex with punctures not distinct; space between lateral ocellus and upper portion of facial fovea smooth, shining with only one or two punctures. Mesoscutum shining, with rather dense, more or less strong, irregular punctures, spaces between punctures slightly elevated, rugae-like; scutellum coarsely rugosopunctate; metanotum roughened, dull ; propodeal enclosure dull, minutely densely lineolate, impunctate ; dorso-lateral face of propodeum more or less coarsely sculptured; mesepisternum shining with weak, shallow punctures. Metasoma shining; 1st tergum with transverse wrinkles in middle, punctures not dense, not strong; 2nd tergum with punctures irregular in distribution, sparse medially; 3rd tergum with punctures closer and smaller than those on 2nd ; impunctate apical margins of basal five terga broad, well indicated.

Color: Head and thorax black; flagellum beneath slightly brownish; legs yellow except for apical segments of tarsi slightly reddened and fore coxae and trochanters variable with yellow and brown (fore coxae usually fuscous, however), Wings distinctly brownish ; stigma and veins brown ; tegulae brownish, partly subhyaline. Metasoma black with weak metallic reflection which is variable in shade of blue, green and purple.

Hairs : Hairs very scanty in front of head; vertex and genal area with sparse, slightly yellowish hairs ; mesoscutum with very short, fine, white hairs; 
metanotum, propodeum except propodeal enclosure, and metepisternum rather hairy, hairs gray; metasoma scanty of hairs; apical margin of 1st tergum with sparse, white, fringe-like hairs on side only; hairs on apical portion of metasoma fuscous.

Male : Length about $10 \mathrm{~mm}$; fore wing about $9 \mathrm{~mm}$.

Very similar to female except sexual differences. Differs from the description of female as follows:

Relative head measurements : width, 39; length, 39; eye length, 30 ; upper interocular distance, 18; width of face, 23; lower interocular distance, 16. 5; length of clypeus, 18. 5 (approximately $10+8$. 5). Mandible bidentate ; malar space very long, about as long as basal width of mandible; clypeo-ocular distance longer than in female, but much shorter than length of malar space; clypeus broadly flat, without median longitudinal ridge ; posterior spur of hind tibia only slightly curved near base; seven terga exposed as usual when metasoma is highly extended, with apex of the tergum rather narrow and obscurely emarginate in middle. Head with yellow markings on clypeus and lower paraocular area or further on labrum, mandible and scape in front. Fringelike white hairs on latero-apical portions of 1st tergum absent. Sterna without modification; 5th sternum more or less hairy, with a fringe of curled, fuscous hairs apically. Genitalia small, not specially modified.

Type material and type depository: Holotype female (BISHOP 11426), Mt. Kaindi, 2,360 m, NE. New Guinea, on Evodia (no flowers but on tree juice), Sept. 1112, 1969 (Y. Hirashima) ; 2 paratopotype females, on Evodia, Aug. 19, 1969 (Y. Hirashima) ; 1 paratopotype female, July 22, 1969 (Y. Hirashima) ; 1 paratopotype female and 1 paratopotype male, on Rubus flowers, Sept. 24-25, 1969 (Y. Hirashima); 1 male, Mt. Piora, NE New Guinea (6" 45 S, 146 E), 1,650 m, June 12, 1966 (0. R. Wilkes) ; 1 female, Edie Creek, near Wau, NE New Guinea, 2, 0502, $300 \mathrm{~m}$, March 31, 1966 (J. L. Gressitt) ; all in the B. P. Bishop Museum, Honolulu.

Distribution : New Guinea.

\section{Palaeorhisa (Sphecogaster) pernigra, new species}

This new species is known by the holotype female only. This is easily separable from the preceding species by the larger and entirely black body, the longer head, the stronger punctation on the thorax, the white hairs on the apex of the metasoma, etc.

Female: Length about $13 \mathrm{~mm}$; wing length about $12 \mathrm{~mm}$.

Relative head measurements : width, 44.5; length, 47 ; eye length, 35.5; upper interocular distance, 22 ; width of face, 28; lower interocular distance, 22.5 ; length of clypeus 22 (approximately $12+10$ ). Inner eye margins, except upper portions above emarginations, slightly converging below ; malar space oblique, widened posteriorly, about as long as basal width of mandible on posterior portion ; clypeo-ocular space broad but much narrower than malar space; mandible tridentate; clypeus broadly flat, with a weak, longitudinal, median elevation; supraclypeal area with upper portion not very much elevated but well distinguished from frons, slightly dilated laterally; ocelli large ; 
postocellar distance shorter than long axis of posterior ocellus, slightly more than half of ocellocular distance, less than half of ocelloccipital distance; ocelloccipital space transversely concave in middle. Mesoscutum well convex; axilla slightly conically convex ; scutellum broadly flat ; propodeal enclosure strongly convex in middle, but elevation slightly weaker than in paradisea, and summit of which is slightly rounded (keel-like in paradisea); mesepisternum with oblique keel in front of mid coxa very strong. Stigma large, rather broad; 2nd submarginal cell large, slightly less than four-fifths of 1st; wings with hairs sparse basally. First tergum small, constricted and subpetiolate at base ; median portion of 1st tergum well convex (slightly more convex than in paradisea); 2nd tergum very strongly convex in middle, strongly depressed at base; apical margin of 6 th tergum broad, slightly rounded,

Face shining but slightly duller than in paradisea; clypeus, supraclypeal area, paraocular area and frons very finely longitudinally lineolate with sparse, very weak punctures like paradisea; frons broadly impunctate above antennae and supraclypeal area; frons lateral to mid ocellus weakly and rather sparsely punctate ; vertex lateral to posterior ocellus nearly smooth, shining, with a few punctures only. Mesoscutum strongly and more or less coarsely punctate on microscopically roughened, rather dull ground, punctures irregular in distribution, much stronger than in paradisea; scutellum coarsely and densely punctate ; metanotum roughened with indication of punctures, dull ; propodeal enclosure impunctate, finely tessellate, dull ; dorso-lateral and posterior faces of propodeum more coarsely punctate than in paradisea; lateral face of propodeum with fine structure (minutely shagreened) nearly all over, impunctate, dull; mesepisternum with punctures not well marked, irregular in size (smaller on upper portion) and distribution; metepisternum with transverse rugae distinct. Metasomal terga very finely lineolate or tessellate, less shining than in paradisea; punctures more or less well marked, slightly denser than in paradisea ; apical impunctate margins of basal four terga broad and more distinctly marked than in paradisea.

Color: Entirely black, including legs; metasoma with weak iridescence on apical impunctate margins of terga; flagellum brownish beneath ; tegulae shining fuscous; wings subhyaline with distal margins slightly darkened; veins and stigma brown, partly paler.

Hairs: Hairs nearly absent in front of head; hairs more or less long, shining silvery on genal area, vertex, side of thorax (except for propodeum with dull white, subappressed, dense hairs) and side as well as apical portion of metasoma; latero-apical portion of 1st tergum with covering of dense, suberect, more or less long, white hairs; similar' but sparser, fringe-like hairs present on the corresponding portions of 2nd tergum.

Type material and type depository : Holotype female (BISHOP 11427), Mt. Bosavi, 2, 300 m, SE New Guinea, May 9, 1973 (J. L. Gressitt), in the B. P. Bishop Museum. Honolulu.

Distribution : New Guinea. 
Subgenus Anchirhiza Michener, 1965

Type-species: Palaeorhiza (Anchirhiza) mandibularis Michener, 1965 ('Monobasic and original designation)

Anchirhiza is known by a single species only. The type species of this subgenus was described from Southern Queensland, Australia. It is known by the female only there at present. I have collected, however, three males and two females of this species from New Guinea in 1969 (Mt. Kaindi, near Wau, Papua New Guinea). Thus, this subgenus is found both in Australia and New Guinea, although this is not common so far as my knowledge is concerned.

The subgenus was elected based on the small clypeus which is broadly separated from the eye, and the extraordinarily broad, edentate mandible of the female. In the male, however, the clypeus is not so broadly separated from the eye, and the mandible is bidentate and not so broad. Characteristic features to the male, however, are that the antenna is elongate with the short scape, and the length of the malar space does not exceed that of the female in proportion. The mode of the punctation and coloration as well as the hirsute condition of Anchirhiza are suggestive of those of Ceratorhiza, although there are slight differences between them.

\section{Description of the subgenus}

Rather large, more or less robust species.

Black ; metasbma slightly metallic ; 1st tergum of male sometimes red; face red (slightly yellowish) in female, yellow in male; collar of pronotum, axilla, large round mark on side of scutellum, and metanotum yellow; legs red (yellowish) except for blackish basal portions.

Rather hairy in female, hairy in male even on metasoma; head and thorax with rather long, brownish to black hairs; metasoma without hair band; apical portion of metasoma with hairs blackish in female, pale brown in male.

Mandible extraordinarily broad and edentate at apex in female, more or less broad and bidentate in male; malar space distinct but shorter than basal width of mandible; clypeus small, broadly separated from eye especially in female ; upper portion of supraclypeal area distinctly elevated, dilated laterally with sharp edge, sharply defined from frons above. Head densely and distinctly punctate. Antenna long in female, very long in male; in female, flagellum with 1st segment longer than broad, longer than 2nd which is about as long as broad, 3rd about one and one-half times as long as broad, longer than 1st; in male, scape short (about three times as long as broad), flagellum with 1st segment as long as broad. 2nd longer than broad, slightly shorter than elongate $3 r d$ and following segments.

Scutellum, metanotum and propodeal enclosure horizontal in side view, especially in female (scutellum of male slightly elevated) ; metanotum broad, flat; propodeal enclosure large, flat, almost all dorsal, well indicated by absence of punctures. Thorax very densely punctate even on side of thorax (lateral face of propodeum with strong and dense punctures all over).

Wings with stigma rather slender; 2nd submarginal cell about two-thirds 

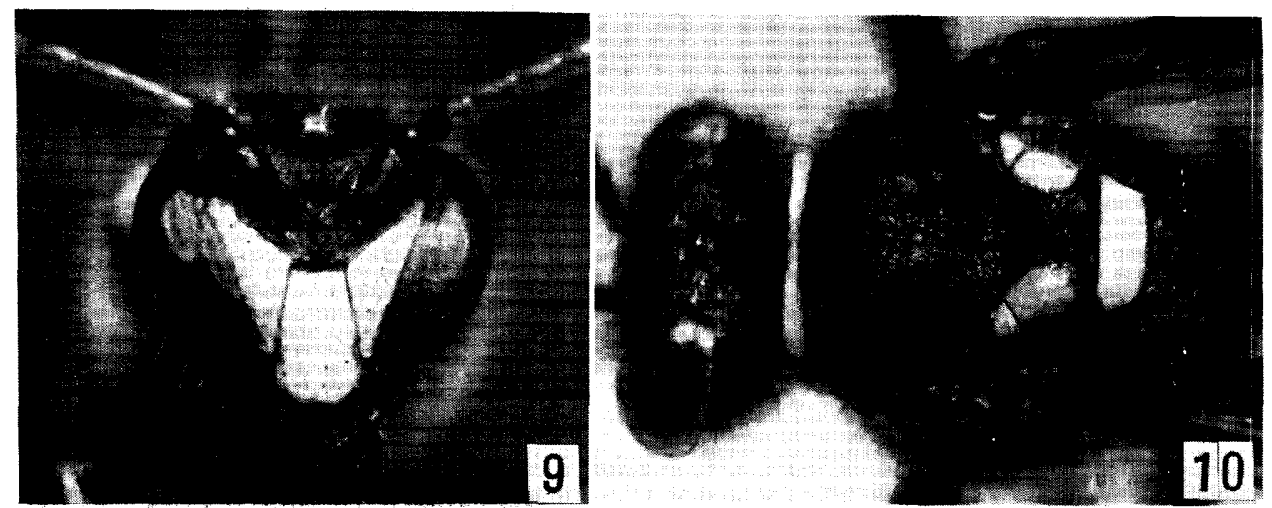

Figs. 9-10. Palaeorhiza (Anchirhiza) mandibularis Michener, male. 9: Frontal view of the head. 10: Dorsal view of the thorax, showing the characteristic markings of the latter.

as long as 1st.

Legs slender; in female, fore tarsus with polliniferous hairs well developed, 1st segment about as long as next four segments together except claw, 2nd only slightly longer than broad, inner apical lobe exceeding outer one, 3rd about as long as broad, slightly oblique; in male, 2nd segment of fore tarsus longer than broad, slightly longer than next segment which is slightly longer than broad; basal portion of hind tibia slender, without special modification; inner hind tibia1 spur of female curved near base, densely and finely ciliate or could be very finely serrate.

Metasoma with female 6th tergum rather pointed at apex; sterna of male without special modification. Metasomal terga very densely and finely punctate, with apical impunctate margins linear. Male genitalia small, not specially modified.

Distribution : Australia and New Guinea.

\section{Palaeorhiza (Anchirhiza) mandibularis Michener}

Palaeorhiza (Anchirhiza) mandibularis Michener, 1965, Bull. Amer. Mus. Nat. Hist., 130: 303, female. Southern Queensland.

Female specimens* from New Guinea well accord with the original description and with my note of mandibularis based on the holotype female borrowed from the Queensland Museum during my visit to the B. P. Bishop Museum in 1966-67. It is very interesting to record the Australian species from the mountain of New Guinea. Michener says that the face marks of the type female are dark yellow, but I describe them as red with yellow shade in this paper. They are slightly more yellowish than the face marks of the female

* In June, 1978, I sent a New Guinean female specimen to Dr. Elizabeth M. Exley, University of Queensland for more detailed comparison with the type of mandibularis. 
of $P$. (Ceratorhiza) rubrifrons, to which the mode of the coloration, except for the yellow metanotum and the black propodeal enclosure, is very similar. Some more features of the female are as follows:

Female: Face rather unusually broad for Palaeorhiza; relative head measurements : width, 42.5 ; length, 35; eye length, 28; upper interocular distance, 24; width of face, 29; lower interocular distance, 23; length of clypeus, 14.5 (approximately $10+4.5$ ) ; width of upper margin of clypeus, 8; clypeo-ocular distance, 5.5. Pronotal yellow band not interrupted; face marks red with more yellow shade and metasoma less matellic than in P. (Ceratorhiza) $r u$ brifrons. Hirsute species with blackish hairs on vertex and mesoscutum, as in rubrifrons. Clypeo-ocular distance broader than broad malar space which is slightly longer than basal half of mandible ; supraclypeal area constricted in middle, upper portion broadened and dilated laterally with sharp edge, gently reducing its height above; facial fovea distinct (longer than in rubrifrons, about as long as in conica). Punctation of thorax suggestive of Ceratorhiza but that on side of thorax including lateral face of propodeum more strong and distinctive. Punctation of metasomal terga denser and finer than in $C e$. ratorhiza.

Male : Length about $8.5 \mathrm{~mm}$; fore wing slightly less than $8 \mathrm{~mm}$.

Relative head measurements : width, 36.5; length, 31; eye length, 24; upper interocular distance, 20; width of face, 23; lower interocular distance, 14; length of clypeus, 13. 5 (approximately $9+4.5$ ) ; width of upper margin of clypeus, 5. 8; clypeo-ocular distance, 3. Inner eye margins very strongly converging below except upper portions; mandible bidentate with upper tooth obliquely rounded at apex ; malar space about as long as clypeo-ocular distance ; clypeus longitudinally convex especially on lower portion; upper portion of supraclypeal area sharply elevated from frons, dilated laterally with sharp edge; ocelli moderate in size, posterior ocelli on top of vertex, postocellar distance about as long as diameter of posterior ocellus, about half as long as ocellocular distance or slightly shorter, which is slightly longer than ocelloccipital distance; eyes rather large in frontal and lateral views. Scape short, about three times as long as broad; flagellum elongate, with 1 st segment as long as broad, 2nd longor than broad, shorter than 3rd which is slightly less than twice as long as broad. Legs slender, rather elongate; claw segments long with strong claws, especially on middle and hind legs; fore tarsus with 1st segment shorter than next four segments together except claw, 2nd segment longer than broad, slightly longer than 3rd which is about as long as broad. Collar of pronotum well convex, rounded, especially on side; scutellum broadly and slightly convex laterally, longitudinally slightly concave in middle; metanotum broad, two-thirds as long as scutellum, flat; propodeal enclosure large; almost triangular, almost all dorsal, well indicated by absence of punctures; transverse carina in front of mid coxa moderate or rather weak. Metasoma long elliptical ; 1st tergum well convex, basal face steep, apical portion broadly constricted ; 2nd tergum well convex, basal portion distinctly constricted; sterna without special modification.

Clypeus, lower (colored) portion of paraocular area, and supraclypeal area strongly punctate; frons, upper paraocular area, vertex, and upper portion of 
genal area exceedingly densely punctate on microscopically roughened ground. Mesoscutum and scutellum exceedingly densely punctate on minutely roughened and very weakly shining ground, punctures small; metanotum also densely and weakly punctate; propodeum except enclosure very densely? rather strongly punctate, punctures distinct even on lateral face of propodeum (often punctures are not distinct on lateral face of propodeum for Palaeorhiza); pre-episternum and mesepisternum very densely, rather strongly regoso-punctate ; metepisternum transversely wrinkled, with an indication of small, dense, transverse punctures on lower portion. Basal four terga of metasoma finely and exceedingly densely punctate on very slightly shining ground, with impunctate apical margins linear ; sterna shining, with coarse, shallow punctures on basal portions of 2 nd to 4 th.

Color: Head and thorax jet black, with following markings or portions yellow : clypeus except apical margin, large triangular' face mark, longitudinal mark on scape in front_ \&sometimes reduced), collar of pronotum, lateral lobe of pronotum, axilla, large round mark on side of scutellum, and metanotum except on side; supraclypeal area with or without yellow marking; flagellum beneath yellowish brown. Wings brownish; veins and stigma brown ; tegulae fuscous. Legs with coxae, trochanters and femora blackish, tibiae and tarsi reddened, or sometimes more broadly darkened or more broadly reddened. Metasoma black or piceous with dark blue-green shade, strong purple tint on venter ; 1st tergum variable in color, nearly all yellowish red to all piceous, metallic when dark

Hairs: Head and thorax with rather long, dense, brownish hairs, those on vertex and mesoscutum blackish; 1st tergum with rather dense, more or less short hairs, hairs brownish when integument dark and white when ground color red; hairs on apical portion of metasoma brownish or sometimes more paler; apical margin of 5th sternum with apical fringe of curled, brownish (or more darker) hairs.

Specimens examined: Two females and three males, Mt. Kaindi, 2,360 m, near Wau, Papua New Guinea, Sept., 1969 (Y. Hirashima). One male was collected on the tree juice of Evodia which was growning near the summit.

Distribution : Australia (Queensland) and New Guinea.

Type depository: Queensland Museum.

\section{Ceratorhiza, new subgenus}

Type-species : Palaeorhiza (Palaeorhiza) conica Michener, 1965

The new subgenus, which is composed of two, rather large to large, robust species, is characteristic in having a prominent conical projection on the propodeal enclosure, a feature unknown among other bees except for Sphecogaster, another new subgenus described in this paper. Ceratorhiza is further distinct in having a unique pattern of coloration, the hirsute thorax which is exceedingly densely punctate, the serrate or pectinate inner hind tibia1 spur of the female, the long malar space, the large and densely punctate metasoma, etc. This is heterogeneous, however, in the pattern and extent of the 
markings of the face, the shape of mandible, the proportion of the male head (including antennae), the structure of the male metasoma, the shape and proportion of the female fore tarsal segments, etc.

\section{Description of the subgenus}

Rather large to large, robust species.

Head black with markings yellow in conica, red in rubrifrons, new species (lower part of male clypeus yellow in rubrifrons, however) ; thorax black with yellow markings on pronotum, lateral lobe of pronotum, axilla, side of scutellum and most part of propodeal enclosure ; metasoma dark green, usually with purple shade; legs red.

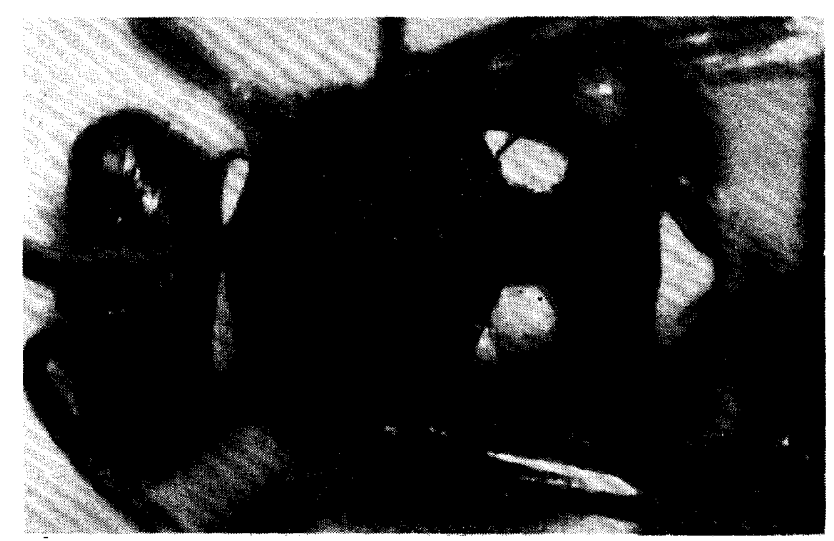

Fig. 11. Palaeorh $i z a$ (Ceratorhiza) rubrifrons, new species. Dorsal view of the thorax, showing the remarkable markings of the thorax and the conically projected propodeal encloure which is characteristic to Ceratorhiza, new subgenus.

Head and thorax, especially the latter, with dense, rather long, brownish to fuscous hairs; metasoma scanty of hairs in female, rather hairy in male.

$M$ andible rather broad and simple at apex in conica, weakly bidentate in rubrifrons; malar space at least as long as basal width of mandible; clypeus broably separated from eye margin (especially in male of conica); inner eye margins subparallel (strongly converging below in male rubrifrons only); upper portion of supraclypeal area distinctly elevated, sharply defined from frons.

In male conica, flagellum with 1st segment longer than broad, 2nd broader than long, 3rd longer than broad, as long as 4th; in male rubrifrons, flagellum long with 1st segment as long as broad, 2nd elongate and much longer than broad, very slightly shorter than 3rd which is as long as 4th.

Propodeal enclosure strongly conically elevated with a rounded apex; thorax extraordinarily densely rugoso-punctate.

Legs slender as usual; basal portion of hind tibia without special modification; inner hind tibial spur of female serrate in conica, pectinate in rubrifrons; that of male finely serrate; polliniferous hairs of female fore tarsus well developed; 2nd and 3rd segments of fore tarsus modified in female conica only. 
Metasoma large, well convex, densely punctate; male 3rd and 4th sterna normal (rubrifrons) or modified (conica); male 5 th sternum with or without apical fringe of curled hairs; male 1st tergum with latero-basal portion strongly convex and shortly keeled in conica, normal (rounded) in rubrifrons. Male genitalia small, not specially modified.

Distribution : New Guinea.

Etymology: The name of the new subgenus refers to the horn-like conical projection on the propodeal enclosure, a feature unknown among other bees. The first component of the new name is adopted from the Greek, keras.

$$
\text { кеу то тне SPECIES оғ Ceratorhiza }
$$

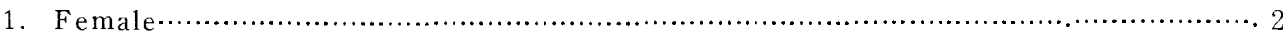

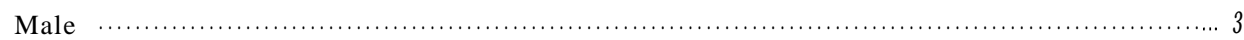

2. Larger, 11- $12 \mathrm{~mm}$; mandible broad and edentate at apex; markings on face not rich, yellow (long and rather broad stripe on paraocular area, triangular mark on apical portion of clypeus and elliptical mark on upper portion of supraclypeal area); flagellum beneath piceous; markings on thorax nearly orange yellow (interrupted band on collar of pronotum, lateral lobe of pronotum, axilla, large round mark on side of scutellum next to axilla, and large mark on propodeal enclosure) ; conical projection on propodeal enclosure, which is yellow, distinctly prominent; propodeum weakly punctate, although punctures dense; inner hind tibial spur serrate with small teeth; fore tarsus with 2nd segment shorter than 3rd, 2nd to 4th flattened, with inner apical lobe exce-

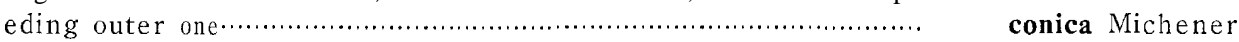
Smaller, slightly less than $10 \mathrm{~mm}$; mandible bidentate at apex; clypeus, supraclypeal area and paraocular area except upper portion red (with slight yellow shade) ; flagellum beneath brownish; markings on thorax similar to conica but lemon yellow; projection on propodeal enclosure, which is lemon yellow, lower; propodeum strongly and densely punctate, punctures distinct even on posterior (vertical) face; inner hind tibial spur pectinate with long teeth; fore tarsal segments normal, although slightly flattened (2nd segment slightly longer than broad, very slightly longer than 3rd, 4th somewhat broader thin

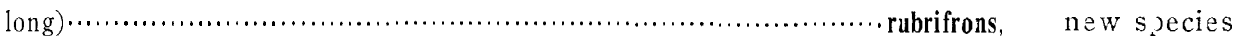

Larger; mandible simple at apex; malar space very long, about twice as long as basal width of mandible ; clypeus narrow, very broadly separated from eye ; inner eye margin converging below; 2nd flagellar segment broader than long, much shorter than 1 st which is longer than broad and about as long as $3 \mathrm{rd}$; yellow markings of face and thorax similar to those of female; propodeum weakly punctate; propodeal projection highly elevated; fore tarsus with 2 nd segment about as broad and long as 3rd; metasoma broadest at base of $1 \mathrm{st}$ tergum which is very convex, provided with a short keel latero-basally; modification of $3 \mathrm{rd}$ and 4 th sterna strong when insect is large; 5th sternum with

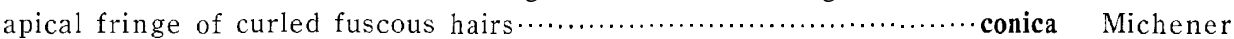
Smaller; mandible bidentate at apex; malar space about as long as basal width of mandible; unlike conica, inner eye margins very strongly converging below; flagellum elongate, 1 st segment as long as broad, 2nd much longer than broad, slightly shorter than 3rd; clypeus, supraclypeal area and paraocular area except upper portion red (slightly yellowish as in female) except for lower part of clypeus pale yellow; yellow markings on thorax similar to female and to conica; fore tarsus slender with 2 nd segment slightly longer than 
3rd; sterna normal; 5 th sternum without fringe of curled hairs; metasoma broadest at 2 nd tergum; 1 st tergum rounded latero-basally as usual, not high-

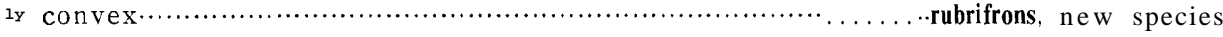

\section{Palaeorhiza (Ceratorhiza) conica Michener}

Palaeorhiza (Palaeorhiza) conica Michener, 1965, Bull. Amer. Mus. Nat. Hist., 130: 301, female. New Guinea.

This is a very distinctive species characterized by the conical projection on the propodeal enclosure and the unique coloration of the body. This is a hirsute species whose head and thorax are covered with dense, rather long, dark (brownish to blackish) hairs.

Female: A fine description has been given by Michener. Comparing to female rubrifrons, new species, facial marks fewer and yellow in color, punctures on propodeum, especially those on posterior (vertical) face, much weaker, metasoma massive and 1st tergum more convex, 2nd to 4th segments of fore tarsus modified, inner hind tibia1 spur serrate with smaller teeth, conical projection on propodeal enclosure more elevated, and punctures on 1st and 2nd terga more dense. Impunctate apical margins of metasomal terga linear or virtually absent. Base of hind tibia with a small longitudinal space smooth, shining, and free of both hairs and punctures.

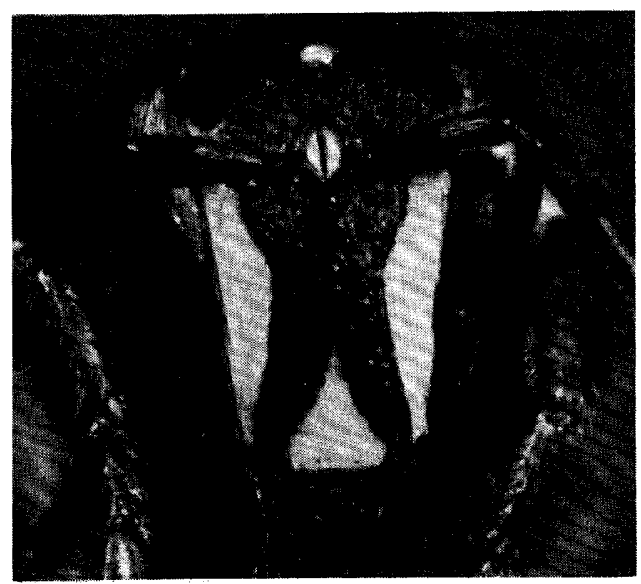

Fig. 12. Frontal v ew of the male head of Palaeorhiza (Ceratorhiza) conica Michener.

Male: Length variable, large to very large, robust.

Very similar to female except for sexual differences. Relative head measurements: width, 42; length, 42; eye length, 28.5; upper interocular distance, 23; width of face, 25; lower interocular distance, 21; length of clypeus, 20.5 (approximately $8+12.5$ ). Face very long as seen in front; inner eye margins only slightly converging below; malar space considerably longer than in female, about twice as long as basal width of mandible; antennae rather 
long; 1st segment of flagellum longer than broad, much longer than 2nd, which is broader than long, 3rd and following segments longer than broad respectively; underside of thorax with transverse keel or carina in front of mid coxa very strong, and space in front of it transversely concave; legs with claws and claw segments large; unlike female, 2nd and 3rd segments of fore tarsus about equal in size and shape, not modified; inner hind tibial spur very finely serrate ; metasoma large, long, broadest at base of 1st tergum which is large and well convex; basal face of 1st tergum steep; 1st tergum with longitudinal short projection or keel on each side basally; 1st tergum large, long, strongly convex in middle ; 3rd sternum with very strong, longitudinal (curved inward apically) carina on each side, broad space between these carinae polished and coarsely punctate, space lateral to the carina sculptured and colored like lateral portion of the corresponding tergum; 4th sternum with polished, impunctate, elevated basal portion defined laterally by similar carina, but this modification indistinct when insect is small; 5th sternum with apical fringe of curled long fuscous hairs ; 5 th and 6th terga with long black hairs not specially dense. Genitalia small, not specially modified.

Specimens examined: 6 females and 4 males, Mt. Kaindi, 2,360 m, Morobe District, Papua New Guinea, August and September, 1969 (Y. Hirashima).

Flower record: Two females were taken on the Rubus flowers which were blooming near the summit of Mt. Kaindi.

Distribution: Papua New Guinea (Western Highlands District and Morobe District). As far as known, this species inhabits the mountainous regions of more than $2,000 \mathrm{~m}$ altitude,

\section{Palaeorhiza (Ceratorhiza) rubrifrons, new species}

The new species, which is also characterized in having the conical projection on the propodeal enclosure, is easily separable from the preceding species by the smaller size, different markings of the face and other characters listed in the key.

Female: Length slightly less than $10 \mathrm{~mm}$; wing length about $8 \mathrm{~mm}$.

Relative head measurements : width, 39; length 37; eye length, 29; upper interocular distance, 19 ; width of face, 23.5 ; lower interocular distance, 18; clypeal length, 17 (approximately $10+7$ ). Inner eye margins slightly converging below except for upper portions; mandible nearly parallel-sided, weakly bidentate at apex; malar space about as long as basal width of mandible; clypeus and supraclypeal area well convex, the latter sharply defined from frons as in conica; clypeus broadly separated from eye; propodeal enclosure with a conical projection which is less elevated than in conica. Stigma slender but slightly more expanded than in conica; second submarginal cell about twothirds as long as first. Inner hind tibia1 spur pectinate; fore tarsus with 2nd segment very slightly larger than 3rd which is larger than 4 th, as usual.

Clypeus finely longitudinally lineolate with longitudinally elongate, more or less coarse punctures which are irregular in size, weaker than in conica; supraclypeal area more finely longitudinally lineolate ; colored portion of paraocular area like clypeus; upper portion of paraocular area, frons and vertex 
extremely aensely punctate, punctures very small; unlike conica, no impunctate "space lateral to each lateral ocellus. Thorax densely to extremely densely punctate; punctation on mesoscutum, scutellum and metanotum similar to that of conica but punctures on side of thorax and propodeum stronger and coarser, especially on the latter; propodeal enclosure impunctate and with rather dull sericeous lustre as in conica. Metasoma shining (dull in some specimens), punctation similar to conica but punctures sparser on median portion of 1st and 2nd terga; sterna shining, coarsely and sparsely punctate as in conica.

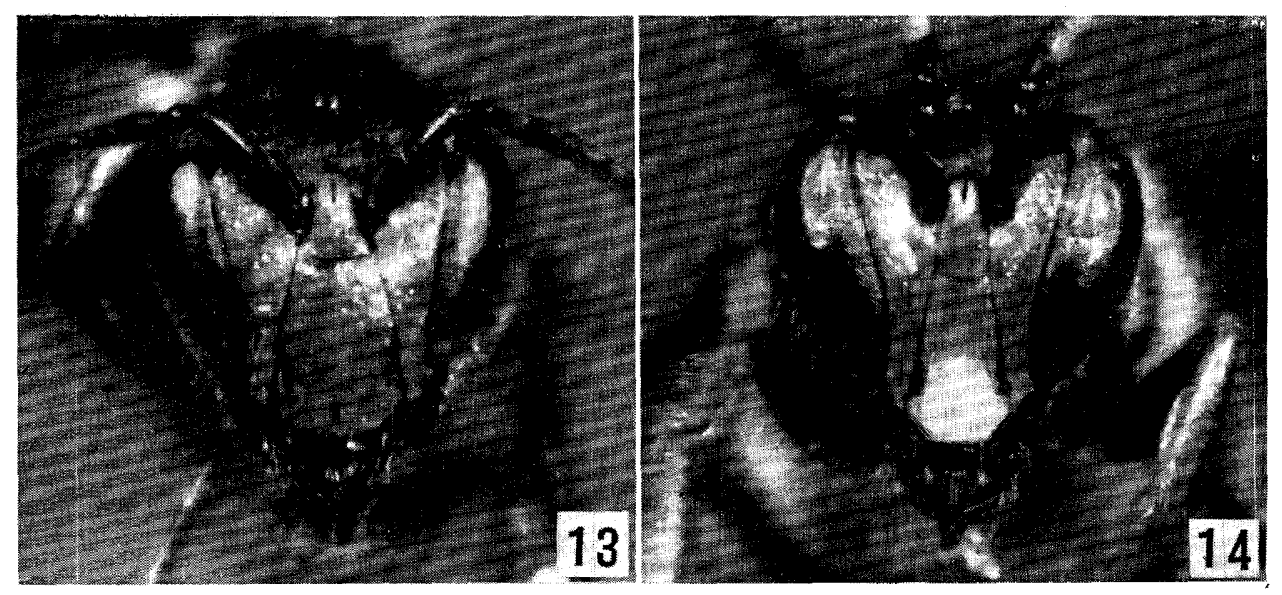

Figs. 13-14. Frontal view of the head of Palaeorhiza (Ceratorhiza) rubrifrons, new species. 13: Female. 14: Male.

Color: Head black with clypeus, supraclypeal area and paraocular area below emargination of eye (obliquely to antennal base) red (with slight yellowish shade in some specimens); flagellum broadly brownish beneath; thorax black with following marks or portions lemon yellow: interrupted band on collar of pronotum, posterior lobe of pronotum, axilla, large round mark on side of scutellum next to axilla, and propodeal triangle. Legs red except for coxae, trochanters and most parts of femora. Wings uniformly slightly brownish, slightly paler than in conica. Metasoma dark green, with slight (in the holotype) to strong purple tint; metasoma nearly all purple in some specimens.

Hairs: Head and thorax with dense, rather long hairs, whitish on face and lower part of genal area, fuscous or nearly black on front, vertex, mesoscutum, scutellum (except for colored portions) and metanotum, ochreous elsewhere; hairs scanty on metasoma ; 1st tergum with a fringe-like covering of ochreous hairs on latero-apical portion not always distinct; hairs on apex of metasoma black.

Male: Length about $9 \mathrm{~mm}$; wing length about $8 \mathrm{~mm}$.

Very similar to female except for sexual differrences. Differs from the description of female as follows : 
Relative head measurements : width, 38; length, 37; eye length, 28.5 ; upper interocular distance, 19; width of face, 22; lower interocular distance, 14; length of clypeus, 16 (approximately $9+7$ ). Face narrow (much narrower than in conica); inner eye margins strongly converging below except for upper one-fourth which converges strongly toward ocelli; mandible more weakly bidentate at apex; flagellum long, with 1st segment as long as broad, 2nd unusually elongate for species of Palaeorhiza, about as long as 3rd (or very slightly shorter than 3rd); inner hind tibia1 spur very finely serrate; fore tarsus slender, 2nd segment longer than 3rd, both unmodified; 3rd and 4th metasomal sterna without special modification. Punctures on 1st and 2nd terga denser than in female, stronger than in male conica; broad impunctate apical margins of 2 nd to 4 th sterna well indicated, very narrow on each side. About lower half of clypeus pale yellow (upper half red as in female) ; metasoma shining dark green, with strong purple tint. Hairs slightly paler than in female; 1st tergum hairy, hairs ochreous, slightly dense on side; 2nd and following terga with fuscous to black hairs; unlike conica, 5th sternum without apical fringe of hairs. Genitalia small, not specially modified.

Type material and type depository: Holotype female (BISHOP 11428) and 4 females, Wisselmeren, Enarotadi 1,900 m, NW New Guinea, August 2-12, 1962, by Malaise trap (J. Sedolacek) ; 1 female and 1 male, July 2-August 4, 1962 (J. Sedolacek) ; 2 females, Mt. Bosavi, 1,800 m, Southern Highlands, Papua New Guinea, June, 1973 (Gaya); 1 female, Mt. Missim, 1,600 m, Morobe District, Papua New Guinea, May 27, 1966, by Malaise trap (J. L. Gressitt) ; 1 female, Wau, Nami Creek, 1,670 m, Morobe District, Papua New Guinea, August 26, 1963, by Malaise trap (J. Sedolacek) ; in the Bernice P. Bishop Museum, Honolulu.

Distribution : New Guinea.

Postscript: Dr. E. M. Exley of University of Queensland has kindly compared for me the New Guinean specimen with the type of Palaeorhiza (Anchi. rhiza) mandibularis Michener and is convinced that it is mandibularis (personal communication, September 14, 1978). I am grateful to her. 